\title{
ANALISIS MAKRO EKONOMI DAN INDEKS DOW JONES TERHADAP VOLATILITAS PASAR SAHAM INDONESIA
}

\author{
Noviarti \\ Dosen Tetap Program S1 Jurusan Manajemen Fakultas Ekonomi Universitas Satya Negara Indonesia \\ noviarti.arif@gmail.com
}

\begin{abstract}
This study aims to determine how macroeconomic factors and the Dow Jones Index affect the volatility of the Indonesian stock market. Volatility The Indonesian stock market is represented by Indonesia Composite Index, and macroeconomic factors are represented by variables of Inflation, Exchange Rate, BI Rate, Gold Price and American Capital Market Performance represented by the Dow Jones Index. Observation period from January 1, 2018 to January 15, 2018 with daily data. From the results of the test data obtained results that the Exchange Rate and Dow Jones Index significantly affect the volatility of Indonesian stock market prices during the observation period. Inflation variables, BI rates and gold prices have no significant effect.
\end{abstract}

Keywords: Macroeconomics, Dow Jones Index, ICI

\section{PENDAHULUAN}

Investor harus memastikan bahwa keputusan investasi yang diambilnya memberikan return yang sebanding dengan risiko yang ditanggungnya. Untuk itu perlu ditentukan terlebih dahulu berapa besar risiko suatu saham. Ukuran risiko dapat dilihat dari volatilitas saham, apabila saham semakin berfluktuatif akan semakin berisiko. Naik turunnya harga-harga saham yang tercatat akan terlihat melalui pergerakan indeks atau lebih dikenal dengan Indeks Harga Saham Gabungan (IHSG).

IHSG merupakan nilai yang digunakan untuk mengukur kinerja gabungan seluruh saham (perusahaan/emiten) yang tercatat di Bursa Efek Indonesia (BEI). Dengan adanya indeks, kita dapat mengetahui trend pergerakan harga saham saat ini apakah sedang naik, stabil atau menurun. Indeks harga saham menjadi salah satu barometer bagi investor sebelum melakukan investasi di pasar saham, karena dari Indeks harga saham dapat diketahui situasi gambaran secara umum. Indeks harga saham merupakan ringkasan dari dampak simultan dan kompleks atas berbagai macam faktor yang berpengaruh, terutama fenomena-fenomena ekonomi. Bahkan saat ini, indeks harga saham dijadikan barometer kesehatan ekonomi suatu negara serta sebagai landasan analisa statistik atas kondisi pasar terakhir (current market). Kebijakan moneter oleh bank sentral Amerika Serikat (AS), The Fed menaikkan target bunga Federal fund pada rapat Federal Open Market Committee (FOMC) tanggal 20-21 Maret 2018. Dan memutuskan untuk menaikkan kisaran bunga ke 1,5\%-1,75\%. Tanggal 22 Maret 2018, IHSG turun ke 6,254.074 dari sehari sebelumnya 6,312.831 Artinya IHSG anjlok sampai 0,93\%. Pada 3 Mei 2018 setelah malamnya pengumuman kenaikan bunga Fed fund meluncur, IHSG ditutup anjlok ke 5.858.732. Itu berarti IHSG anjlok hingga 2,55\%. pada 12 Juni-13 Juni FOMC yang beranggotakan para gubernur bank negara bagian Amerika Serikat itu bersidang. Hasilnya, FOMC menaikkan range target bunga Fed Fund ke 1,75\% sampai 2\%. Baru tanggal 20 Juni 2018 setelah pasar bursa libur Lebaran para trader dan investor di BEI bersikap. IHSG langsung dibuka dengan gap turun, Pada saat bursa tutup di sore hari, IHSG turun ke 5.884.039 atau turun 1,89\% dibanding penutupan 8 Juni.

Dari sisi global, menguatnya potensi perang dagang menjadi salah satu penyebab jatuhnya IHSG. Awal mula terjadinya perang dagang saat AS mengenakan bea masuk kepada 
produk-produk impor dari beberapa Negara seperti China, Kanada hingga Uni Eropa. Pengenaan bea masuk ini dengan mempertimbangkan defisit perdagangan yang selama ini diderita oleh Negeri Paman Sam. China merupakan salah satu negara yang menjadi sasaran utama pengenaan bea impor tersebut.

Hal ini dikarenakan, tahun ini hingga Mei 2018, AS sudah mengalami defisit perdagangan sampai US\$ 155,2 miliar. Angka tersebut meningkat hingga 9,9\% dibandingkan periode yang sama pada tahun sebelumnya. Maka AS kembali mengenakan bea masuk tambahan bagi produkproduk impor dari China.

Pada 6 juli 2018, AS resmi memberlakukan bea masuk tambahan sebesar 25\% untuk 818 produk China. China pun membalas dengan mengenakan bea masuk $25 \%$ untuk 659 produk AS. Aksi ini membuat terganggunya situasi ekonomi global. Akibatnya,kekhawatiran investor pun meningkat dan menyebabkan bursa saham di kawasan Asean termasuk Indonesia terimbas dampaknya. Adanya perang dagang, berpotensi mendorong aliran hot money ke Indonesia berkurang. Maka kondisi ini dapat menyebabkan IHSG akan tetap bertahan di zona merah pada beberapa waktu kedepan.

Aspek ekonomi memberikan pengaruh yang sangat besar terhadap pasar modal di bandingkan aspek-aspek lainnya. Oleh karena itu perlu mendapatkan perhatian yang sangat besar. Aspek ekonomi sering disebut sebagai aspek makro yang terdiri atas nilai tukar,inflasi,tingkat bunga,harga emas, harga minyak dunia,risiko politik,risiko pasar dan indikator ekonomi lainnya. Peningkatan tingkat inflasi akan menyebabkan kebijakan ekonomi yang lebih ketat dan akan membuat efek negatif terhadap harga saham. Efek negatif yang diterima oleh harga saham ini tentunya akan membuat pergerakan harga semakin tidak menentu dan pada akhirnya akan menyebabkan volatilitas harga yang tinggi.

Kurs merupakan variabel makroekonomi yang turut mempengaruhi volatilitas harga saham. Depresiasi mata uang domestik akan meningkatkan volume ekspor. Bila permintaan pasar internasional cukup elastis hal ini akan meningkatkan cash flow perusahaan domestik, yang kemudian meningkatkan harga saham, yang tercermin pada IHSG. Sebaliknya, jika emiten membeli produk dalam negeri, dan memiliki hutang dalam bentuk dollar maka harga sahamnya akan turun. Depresiasi kurs akan menaikkan harga saham yang tercermin pada IHSG dalam perekonomian yang mengalami inflasi.Depresiasi kurs akan menaikkan harga saham yang tercermin pada IHSG dalam perekonomian yang mengalami inflasi. Suku bunga BI merupakan tingkat suku bunga yang ditetapkan oleh BI sebagai patokan bagi suku bunga pinjaman maupun simpanan bagi bank dan atau lembaga-lembaga keuangan di seluruh Indonesia.

Suku bunga merupakan salah satu variabel yang dapat mempengaruhi harga saham. Perubahan tingkat suku bunga selanjutnya akan mempengaruhi keinginan seseorang untuk melakukan suatu investasi,karena secara umum perubahan suku bunga SBI dapat mempengaruhi suku bunga deposito dan suku bunga kredit di masyarakat. Jika Suku bunga deposito meningkat maka investor cenderung menanamkan modalnya dalam bentuk deposito karena dapat menghasilkan return yang besar dengan resiko yang lebih kecil dan sebaliknya. Secara umum volatilitas pasar keuangan menggambarkan tingkat risiko yang dihadapi pemodal karena mencerminkan fluktuasi pergerakan harga saham. Dalam berbagai kasus volatilitas di pasar keuangan dapat mengakibatkan dampak yang signifikan bagi perekonomian. Fluktuasi atau naik turunnya harga saham dapat dilihat degan volatilitas (Sejak awal tahun, rupiah sudah melemah 6,6\% terhadap dolar Amerika Serika. Dalam APBN 2018, rupiah mematok asumsi rata-rata nilai tukar di Rp 13.400/US\$. Sejak awal tahun hingga bulan juli 2018, rata-rata nilai tukar adalah Rp $13.844,51 / \mathrm{US} \$$.

Dari fenomena dan hasil peneliti yang terdahulu yang hasilnya ada yang tidak konsisten dengan teori yang dituangkapkan diatas maka peneliti tertarik untuk melakukan penelitian tentang volatilitas harga saham. Penelitian ini membatasi penelitian terhadap faktor yang mempengaruhi Volatilitas Harga Saham, yaitu inflasi, nilai tukar,BI Rate,Harga Emas Dunia dan Indeks Dow Jones. 


\section{Rumusan Masalah}

1. Bagaimana pengaruh inflasi terhadap Volatilitas Pasar Saham Indonesia?

2. Bagaimana pengaruh nilai tukar terhadap Volatilitas Pasar Saham Indonesia?

3. Bagaimana pengaruh BI rate terhadap Volatilitas Pasar Saham Indonesia?

4. Bagaimana pengaruh harga emas dunia terhadap Volatilitas Pasar Saham Indonesia?

5. Bagaimana pengaruh Indeks Dow Jones terhadap Volatilitas Pasar Saham Indonesia?

6. Bagaimana pengaruh secara simultan Inflasi,Kurs,BI Rate,Harga emas dan Indeks Dow Jones terhadap Volatilitas Pasar Saham Indonesia.

\section{TINJAUAN PUSTAKA}

Harga saham berubah di pasar modal disebabkan oleh faktor permintaan dan penawaran.Variabel yang mempengaruhi permintaan dan penawaran bermacam-macam, ada yang rasional tetapi adapula yang irasional. Pengaruh yang sifatnya rasional mencakup kinerja perusahaan, tingkat bunga, tingkat inflasi, tingkat pertumbuhan, kurs valuta asing ataupun indeks harga saham dari negara lain (Samsul, 2015: 137).

\section{PASAR MODAL}

\section{Pengertian Pasar Modal}

Pasar modal (capital market) adalah pasar yang mempertemukan pihak yang menawarkan dan yang memerlukan dana jangka panjang, seperti saham dan obligasi. Pasar modal merupakan sarana pendanaan bagi perusahaan maupun institusi lain, misalnya pemerintah. Dengan demikian pasar modal memfasilitasi berbagai sarana dan prasarana kegiatan jual beli dan kegiatan terkait lainnya.

Pasar modal memberikan berbagai alternatif untuk para investor selain berbagai investasi lainnya, seperti menabung di bank, membeli tanah, asuransi, emas dan sebagainya. Pasar modal merupakan penghubung antara investor (pihak yang memiliki dana) dengan perusahaan (pihak yang memerlukan dana jangka panjang) ataupun institusi pemerintah melalui perdagangan instrumen melalui jangka panjang, seperti surat berharga yang meliputi surat pengakuan utang, surat berharga komersial (commercial paper), saham, obligasi, tanda bukti hutang, waran (warrant), dan right issue. Pasar modal juga merupakan salah satu cara bagi perusahaan dalam mencari dana dengan menjual hak kepemilikan perusahaan kepada masyarakat. Pengertian pasar modal secara umum adalah suatu sistem keuangan yang terorganisasi, termasuk didalamnya adalah bank-bank komersial dan semua lembaga perantara dibidang keuangan, serta keseluruhan surat-surat berharga yang beredar.

\section{Fungsi Pasar Modal}

Menurut Abdul Halim (2015) pasar modal memiliki peran besar bagi perekonomian suatu negara karena pasar modal menjalani fungsi sekaligus, yaitu :

a. Fungsi ekonomi, dalam hal ini pasar modal menyediakan fasilitas atau wahana yang mempertemukan dua kepentingan, yaitu pihak yang memiliki kelebihan dana (investor) dan pihak yang memerlukan dana (isuuer) jangka panjang.

b.Fungsi keuangan, dalam hal ini pasar modal memberikan kemungkinan dan kesempatan memperoleh return atau capital gain atau interest bagi investor sesuai dengan karakteristik investasi yang dipilih.

\section{Manfaat Pasar Modal}

Beberapa manfaat dari keberadaan pasar modal adalah sebagai berikut:

1. Menyediakan sumber pembiayaan (jangka panjang) bagi dunia usaha sekaligus memungkinkan alokasi sumber dana secara optimal.

2. Memberikan fasilitas investasi bagi investor sekaligus memngkinkan upaya diversifikasi. 
3. Memungkinkan penyebaran kepemilikan, keterbukaan, profesionalisme, serta penciptaan iklim berusaha yang sehat.

4. Memberikan kesempatan memiliki perusahaan yang sehat dan mempunyai prospek.

5. Menjadi alternatif investasi yang memberikan potensi keuntungan dengan risiko yang bisa diperhitungkan melalui keterbukaan, likuiditas, dan diversifikasi investasi.

\section{SAHAM}

Menurut Sunariyah (2011:125) Saham adalah surat berharga sebagai bukti penyertaan atau pemilikan individu maupun institusi yang dikeluarkan oleh sebuah perusahaan yang berbentuk Perseroan Terbatas. Saham menyatakan bahwa pemilik saham tersebut adalah juga pemilik sebagian dari perusahaan terbatas. Dalam pasar modal ada dua jenis saham yang paling umum dikenal oleh publik yaitu saham biasa dan saham istimewa.

\section{Indeks Harga Saham Gabungan}

IHSG adalah singkatan dari Indeks Harga Saham Gabungan. Yang dimaksud dengan indeks harga di sini adalah harga rata-rata dari semua saham yang ada di Bursa Efek Indonesia. Kalau dalam bahasa Inggris IHSG ini disebut dengan Indonesia Composite Index, disingkat ICI, atau IDX Composite. Di Amerika Serikat ada namanya Dow Jones Industrial Average (DJIA) atau Indeks Dow Jone. Secara umur, DJIA ini merupakan indeks tertua yang ada di US dan masih aktif digunakan hingga saat ini.

Jogiyanto (2013 :147), Indeks Harga Saham Gabungan merupakan angka indeks harga saham yang sudah disusun dan dihitung dengan menghasilkan trend, dimana angka indeks adalah angka yang diolah sedemikan rupa sehingga dapat digunakan untuk membandingkan kejadian yang dapat berupa perubahan harga saham dari dari waktu ke waktu.

Indeks saham adalah harga saham yang dinyatakan dalam angka indeks (Samsul: 2006). Indeks saham bertujuan untuk menganalisis dan menghindari dampak negatif dari penggunaan harga saham dalam rupiah. Dalam prakteknya, oleh banyak trader saham, mereka menggunakan pergerakan IHSG ini tujuannya sebagai pertimbangan untuk melakukan trading atau transaksi saham. Ini dikarenakan kondisi Bullish atau Bearish dari IHSG selalu mempengaruhi pergerakan harga saham pada umumnya di BEI. Memang tidak selamanya jika IHSG sedang downtrend maka saham yang kita pegang juga akan ikut turun.

Berdasarkan defenisi IHSG di atas, maka fungsi IHSG adalah:

1. Untuk mengukur kinerja pertumbuhan pasar saham di Indonesia. Semakin tinggi nilainya, maka akan menandakan bahwa harga rata-rata saham semakin meningkat dan semakin besar pula Market Cap nya.

2. Untuk mengetahui arah pergerakan perdagangan saham secara keseluruhan di Bursa Efek Indonesia. Dengan mengetahui pergerakan tersebut, apakah sedang downtrend atau uptrend, maka kita bisa mengetahui apakah kondisi pasar sedang lesu atau tidak.

3. Sebagai dasar pertimbangan bagi para trader saham untuk mengambil keputusan transaksi, apakah membeli atau menjual saham yang ia pegang. Mengapa? Karena seperti telah disebut di atas bahwa saham-saham likuid umumnya sangt terpengaruh oleh pergerakan IHSG.

4. Sebagai patokan kinerja portofolio trader. Maksudnya, bagi orang yang bermain saham, ia bisa menilai sejauh mana kinerja investasinya jika dibandingkan dengan IHSG. Jika misalnya IHSG telah naik $15 \%$ dalam setahun terakhir sedang 
portofolionya $20 \%$ dalam setahun, maka itu artinya kinerja investasinya lebih baik.

\section{Dow Jones Industrial Average (DJIA)}

Dow Jones Industrial Average (DJIA) adalah salah satu indeks pasar saham yang didirikan oleh editor The Wall Street Journal dan pendiri Dow Jones \& Company Charles Dow. Dow membuat indeks ini sebagai suatu cara untuk mengukur performa komponen industri di pasar saham Amerika. Saat ini DJIA merupakan indeks pasar AS tertua yang masih berjalan. Sekarang, bursa saham ini terdiri dari 30 perusahaan terbesar di Amerika Serikat yang sudah secara luas go public.

\section{Volatilitas Harga Saham}

Menurut Tim Studi Volatilitas Pasar Modal Indonesia dan Perekonomian Dunia (2011), volatilitas merupakan pengukuran statistik untuk fluktuasi harga suatu sekuritas atau komoditi selama periode tertentu. Mengingat volatilitas dapat direpresentasikan dengan simpangan baku (standard deviation), publik juga mempersepsikan volatilitas sebagai risiko. Semakin tinggi tingkat volatilitas, semakin tinggi pula tingkat ketidakpastian dari imbal hasil (return) saham yang dapat diperoleh. Salah satu dari sepuluh prinsip manajemen keuangan menyatakan bahwa investor tidak akan mau mengambil risiko yang lebih tinggi kecuali apabila dapat memperoleh kompensasi berupa return yang lebih tinggi (high risk, high return).

Aspek ekonomi merupakan aspek pertama yang harus diperhatikan sebelum aspek industri dan aspek perusahaan.Aspek ekonomi diperlukan untuk menentukan kondisi secara makro/keseluruhan dan melihat lingkungan pasar saham pada saat ini kondusif/ tepat atau tidak.Kondisi ekonomi ini perlu diketahui antara lain, Inflasi,Kurs (nilai Tukar),BI Rate,Harga Emas,Kondisi negara Super Power, dan sebagainya.(Sukmawati:179)

\section{INFLASI}

Inflasi diartikan sebagai suatu proses kenaikan harga - harga yang berlaku dalam suatu perekonomian. Tingkat inflasi (persentasi pertambahan kenaikan harga) berbeda dari satu periode ke periode lainnya, dan berbeda pula dari satu negara ke negara lain. (Sadono Sukirno, 2015)

Pada saat tingkat harga secara umum naik, pembeli harus mengeluarkan lebih banyak uang untuk jumlah barang dan jasa yang sama. Jika konsumen tidak dapat menemukan uang lebih untuk membeli barang demi mempertahankan tingkat pembelanjaannya, mereka akan membatasi pembelian dengan membeli lebih sedikit yang kemudian pada akhirnya akan membatasi kemampuan penjual untuk menaikkan harga. (Itsna Shofi, 2016: 28)

Berdasarkan penjelasan di atas, ciri-ciri inflasi adalah: (Karya \& Syamsuddin, 2016: 89) dalam (Itsna Shofi, 2016: 28-29)

a. Jumlah uang beredar lebih banyak dibandingkan dengan jumlah barang beredar; aggregate demand (AD) lebih besar dari aggregate supply (AS).

b. Harga cenderung naik secara terus menerus. Dengan demikian, jika harga naik hanya seketika dan kemudian turun kembali atau harga naik tidak terus-menerus, maka belum dapat dikatakan terjadinya inflasi.

c. Nilai tukar uang mengalami penurunan.

\section{Jenis-Jenis Inflasi}

Inflasi terbagi atas beberapa pandangan dalam menentukan jenis-jenis atau macam-macam inflasi seperti jenis-jenis inflasi berdasarkan tingkat keparahannya, berdasarkan penyebabnya, berdasarkan asalnya, berdasarkan pengaruh terhadap harga barang antara lain sebagai berikut:

a. Jenis-Jenis Inflasi Berdasarkan Tingkat Keparahannya 
1. Inflasi Ringan adalah inflasi yang belum terlalu mengganggu keadaan ekonomi. Inflasi ringan mampu dikendalikan dengan tingkat nilai dibawah $10 \%$ per tahun.

2. Inflasi Sedang adalah inflasi yang dapat menurunkan kesejahteraan masyarakat bagi penghasilan tetap dengan tingkat laju inflasi sebesar 10\%-30\% per tahun.

3. Inflasi Berat adalah inflasi yang mampu mengacaukan perekonomian yang berakibat pada kurangnya minat masyarakat dalam menabung karna bunga bank lebih rendah dari laju angkat inflasi, inflasi berat memiliki laju sekitar 30\%-100\% per tahun.

4. Inflasi Sangat Berat atau Hiperinflasi adalah inflasi yang telah mengacaukan kondisi perekonomian dan sulit dikendalikan walaupun dengan melakukan kebijakan moneter atau kebijakan fiskal dengan laju inflasi diats $100 \%$ per tahun.

b. Jenis-Jenis Inflasi Berdasarkan Penyebabnya

1. Inflasi Permintaan (Demand Pull Inflation) adalah inflasi yang timbul akibat dari kenaikan permintaan masyarakat

2. Inflasi Biaya (Cost Push Inflation) biaya adalah inflasi yang timbul akibat dari biaya produksi barang dan jasa

c. Jenis-Jenis Inflasi Berdasarkan Asal atau Sumbernya

1. Inflasi dalam Negeri adalah inflasi yang terjadi akibat defisit anggaran belanja negara (APBN) sehingga pencetakan uang baru dan gagalnya pasar yang mengakibatkan tingginya harga bahan makanan.

2. Inflasi Luar Negeri adalah inflasi yang disebabkan naiknya harga barang impor yang berasal dari biaya produksi barang di luar negeri yang tinggi atau naiknya tarif impor barang.

d. Jenis-Jenis Inflasi Berdasarkan Pengaruh terhadap Harga Barang

1.Inflasi Tutup atau (Closed Inflation) adalah inflasi yang terjadi akibat kenaikan harga antara satu atau dua barang tertentu.

2.Inflasi Terbuka (Open Inflation) adalah inflasi yang terjadi akibat kenaikan harga semua barang.

\section{KURS (Nilai Tukar)}

Kurs valuta asing dapat juga didefinisikan sebagai jumlah uang domestik yang dibutuhkan, yaitu banyaknya rupiah yang dibutuhkan untuk memperoleh satu unit mata uang asing. Menurut (Sadono Sukirno, 2015).

Nilai tukar uang merepresentasikan tingkat harga pertukaran dari satu mata uang ke mata uang lainnya dan digunakan dalam berbagai transaksi, antara lain transaksi perdagangan internasional, turisme, investasi internasional ataupun aliran uang jangka pendek antarnegara yang melewati batas-batas geografis ataupun batas-batas hukum. (Yuniarti, 2016: 143).

\section{Sistem Nilai Tukar}

Dalam suatu negara, satu-satunya institusi resmi yang dapat mengubah penawaran mata uang adalah Bank Sentral dari negara tersebut. Bank Sentral dalam kesehariannya acap kali menjual dan membeli mata uang asing. Setiap Bank Sentral dapat memilih antara dua sistem nilai tukar, yaitu: (Karim, 2015: 160).

a. Fixed Exchange Rate System, yaitu nilai tukar mata uang yang ditetapkan pada tingkat tertentu terhadap mata uang asing oleh otoritas keuangan suatu negara.

b. Floating Exchange Rate System, yaitu nilai tukar mata uang suatu negara ditentukan oleh permintaan dan penawaran mata uang di pasar uang. Dalam konsep ini, nilai tukar mata uang dibiarkan bergerak secara bebas.

\section{Pengaruh Nilai Tukar Rupiah Terhadap Pergerakan Indeks Harga Saham Gabungan}

Fluktuasi nilai tukar rupiah terhadap mata uang asing akan sangat mempengaruhi investasi pada pasar modal Indonesia. Perusahaan-perusahaan di Indonesia yang sudah go public dengan masih mengandalkan bahan baku impor dari luar negeri akan menerima dampak negatif apabila mata uang rupiah terdepresiasi atau mengalami pelemahan terhadap mata uang dollar AS. 
Hal ini akan mengakibatkan naiknya bahan baku tersebut. Kenaikan biaya produksi akan mengurangi tingkat keuntungan perusahaan sehingga akan mendorong investor untuk melakukan aksi jual terhadap saham-saham yang dimilikinya. Apabila banyak investor yang melakukan hal tersebut, tentu akan mendorong penurunan indeks harga saham gabungan.

\section{BI RATE}

BI rate adalah suku bunga kebijakan yang mencerminkan sikap kebijakan moneter yang ditetapkan oleh bank Indonesia dan diumumkan kepada publik. BI rate diumumkan oleh Dewan Gubernur Bank Indonesia setiap Rapat Dewan Gubernur bulanan dan diimplementasikan pada operasi moneter yang dilakukan Bank Indonesia melalui pengelolaan likuiditas di pasar uang untuk mencapai sasaran operasional kebijakan moneter. Dengan mempertimbangkan faktorfaktor lain dalam perekonomian, Bank Indonesia pada umumnya akan menaikkan BI rate apabila inflasi ke depan diperkirakan melampaui sasaran yang ditetapkan, sebaliknya Bank Indonesia akan menurunkan BI rate apabila inflasi ke depan diperkirakan berada di bawah sasaran yang telah ditetapkan.

Pengaruh Suku Bunga SBI Terhadap Pergerakan Indeks Harga Saham Gabungan Sertifikat Bank Indonesia (SBI) adalah surat berharga yang dikeluarkan oleh Bank Indonesia sebagai pengakuan utang berjangka waktu pendek dengan sistem diskonto/bunga. Perubahan tingkat suku bunga SBI akan memberikan pengaruh bagi pasar modal. Apabila tingkat suku bunga naik maka secara langsung akan meningkatkan beban bunga. Perusahaan yang mempunyai leverage yang tinggi akan mendapatkan dampak yang sangat berat terhadap kenaikan tingkat bunga. Kenaikan tingkat bunga ini dapat mengurangi profitabilitas perusahaan sehingga dapat memberikan pengaruh terhadap harga saham perusahaan yang bersangkutan. Selain kenaikan beban bunga, tingkat suku bunga SBI yang tinggi dapat menyebabkan investor tertarik untuk memindahkan dananya ke deposito. Hal ini terjadi karena kenaikan tingkat suku bunga SBI akan diikuti oleh bank-bank komersial untuk menaikkan tingkat suku bunga simpanan. Apabila tingkat suku bunga deposito lebih tinggi dari tingkat pengembalian yang diharapkan oleh investor, tentu investor akan mengalihkan dananya ke deposito. Terlebih lagi investasi di deposito sendiri merupakan salah satu jenis investasi yang bebas resiko. Pengalihan dana oleh investor dari pasar modal ke deposito tentu akan mengakibatkan penjualan saham besar-besaran sehingga akan menyebabkan penurunan indeks harga saham. Berdasarkan uraian diatas maka hipotesis dalam penelitian ini adalah sebagai berikut: a. Inflasi berpengaruh negatif terhadap pergerakan indeks harga saham gabungan. b. Nilai tukar rupiah berpengaruh negatif terhadap pergerakan indeks harga saham gabungan.

\section{HARGA EMAS}

Emas banyak dipilih sebagai salah satu bentuk investasi karena nilainya cenderung stabil dan naik. Ketika akan berinvestasi, investor akan memilih investasi yang memiliki tingkat imbal balik tinggi dengan resiko tertentu atau dengan resiko yang rendah. Kenaikan harga emas akan mendorong investor-investor untuk memilih berinvestasi di emas daripada di pasar modal. Sebab dengan resiko yang relative lebih rendah, emas dapat memberikan hasil imbal balik yang baik dengan kenaikan harganya. Ketika banyak investor yang mengalihkan portofolio investasinya ke dalam bentuk emas batangan, hal tersebut diatas ini akan mengakibatkan turunnya indeks harga saham di negara yang bersangkutan karena aksi jual yang akan dilakukan investor. Pengaruh Harga Emas Dunia Terhadap IHSG Sektor Pertambangan Harga emas berdasarkan standar pasar emas London. System ini dinamakan London Gold Fixing adalah prosedur dimana harga emas ditentukan dua kali sehari setiap hari kerja di pasar London oleh lima anggota Pasar London Gold Fixing Ltd. Emas merupakan salah satu bentuk investasi yang cenderung bebas resiko. Emas banyak dipilih sebagai salah satu bentuk investasi karena nilainya cenderung stabil dan naik. Ketika akan berinvestasi, investor akan memilih investasi yang memiliki tingkat imbal balik tinggi dengan resiko tertentu atau dengan resiko yang rendah. Kenaikan harga emas akan 
mendorong investor-investor untuk memilih berinvestasi di emas daripada di pasar modal. Sebab dengan resiko yang relative lebih rendah, emas dapat memberikan hasil imbal balik yang baik dengan kenaikan harganya. Ketika banyak investor yang mengalihkan portofolio investasinya ke dalam bentuk emas batangan, hal tersebut diatas ini akan mengakibatkan turunnya indeks harga saham di negara yang bersangkutan karena aksi jual yang akan dilakukan investor.

\section{METODOLOGI}

Peneliti melakukan peneitian pada pasar saham Indoneia mulai 1 Januari 2018 sampai dengan 15 Juli 2018. Waktu penelitian dilaksanakan dari bulan Maret 2018 sampai dengan selesai.

\section{Desain Penelitian}

Jenis penelitian ini adalah penelitian kausal, yaitu penelitian untuk mengetahui pengaruh antara satu atau lebih variabel bebas (independent variabel) terhadap variabel terikat (dependent variabel).

\section{Hipotesis}

Hipotesis adalah jawaban sementara terhadap penelitian yang keberadaannya harus diuji secara empiris. Hipotesis memberikan keterangan sementara mengenai fenomena yang diteliti, dalam hal ini adalah hubungan antara variabel bebas dan variabel terikat. Maka dapat dirumuskan hipotesisnya sebagai berikut:

\section{Hipotesis Uji Secara Parsial}

Pengujian ini dilakukan untuk menguji apakah setiap variabel bebas mempunyai pengaruh yang signifikan terhadap variabel terikat.
$\mathrm{H}_{1}: \beta \leq 0$
$=$ Tidak terdapat pengaruh inflasi secara signifikan terhadap IHSG
$\mathrm{Ha}_{1}: \beta>0$
$=$ Terdapat pengaruh inflasi secara signifikan terhadap IHSG
$\mathrm{HO}_{2}: \beta \leq 0$
$=$ Tidak terdapat pengaruh nilai tukar rupiah secara signifikan terhadap IHSG.
$\mathrm{Ha}_{2}: \beta>0$
$=$ Terdapat pengaruh nilai tukar rupiah secara signifikan terhadap IHSG.
$\mathrm{HO}_{3}: \beta \leq 0$
$=$ Tidak terdapat pengaruh BI rate secara signifikan terhadap IHSG
$\mathrm{Ha}_{3}: \beta>0$
$=$ Terdapat pengaruh BI rate secara signifikan terhadap IHSG
$\mathrm{H}_{4}: \beta \leq 0$
= Tidak terdapat pengaruh Harga Emas secara signifikan terhadap IHSG
$\mathrm{Ha}_{4}: \beta>0$
$=$ Terdapat pengaruh Harga Emas secara signifikan terhadap IHSG
$\mathrm{H}_{5}: \beta \leq 0$
$=$ Tidak terdapat pengaruh Indeks Dow Jones secara signifikan terhadap IHSG
$\mathrm{Ha}_{5}: \beta>0$
$=$ Terdapat pengaruh Indek Dow Jones secara signifikan terhadap IHSG

\section{Hipotesis Secara Simultan}

Pengujian ini merupakan pengujian yang dilakukan untuk mengetahui apakah variabel bebas secara simultan mempunyai pengaruh yang signifikan terhadap variabel terikat.

$\mathrm{H}_{6}: \beta \leq 0=$ Tidak terdapat pengaruh inflasi, nilai tukar rupiah,BI Rate,Harga Emas, Indeks Dow Jones secara simultan dan signifikan terhadap IHSG

$\mathrm{Ha}_{6}: \beta>0=$ Terdapat pengaruh inflasi, nilai tukar rupiah, BI rate,Harga Emas dan Indeks Dow Jones secara simultan dan signifikan terhadap IHSG

\section{Variabel dan Skala Pengukuran}

Variabel-variabel tersebut terbagi dalam dua jenis variabel, yaitu variabel dependen atau terikat (Y) dan variabel independen atau bebas (X).

1.Variabel dependen atau terikat (Y)

Variabel dependen adalah variabel yang dipengaruhi atau yang menjadi akibat karena adanya variabel bebas. Pada penelitian ini variabel dependen yang digunakan adalah Volatilitas Pasar saham yang diwakili oleh IHSG

2.Variabel Independen atau bebas (X)

Variabel independen adalah variabel yang dapat mempengaruhi atau menjadi penyebab perubahan atau timbulnya variabel dependen/terikat (Y). Pada penelitian ini variabel independen yang di gunakan adalah: 
$\mathrm{X}_{1}=$ Inflasi

$\mathrm{X}_{2}=$ Nilai Tukar Rupiah

$\mathrm{X}_{3}=\mathrm{BI}$ Rate

$\mathrm{X} 4=$ Harga emas Dunia

X5= Indeks Dow Jones

\section{Metode Pengumpulan Data}

Dalam metode pengumpulan data, penulis melakukan dua tahap yaitu:

a. Tahap pertama dilakukan melalui studi pustaka yakni pengumpulan data pendukung berupa literature dan penelitian terdahulu.

b. Tahap kedua dilakukan pengumpulan data menggunakan metode dokumentasi. Metode dokumentasi yang digunakan dalam penelitian ini dilakukan dengan mengumpulkan data yang diperoleh dari situs website resmi yang telah terpercaya.

\section{Jenis Data}

Jenis data yang digunakan dalam penelitian ini adalah data sekunder yaitu data yang telah diolah lebih lanjut dan telah disajikan oleh pihak lain. Data Bank Indonesia mengenai inflasi, nilai tukar rupiah dan BI rate. Dengan periode 1 Januari 2018- 15 Juli 2018 untuk masing-masing variabel.

\section{Populasi Dan Sampel}

Populasi adalah objek atau subjek yang mempunyai kualitas dan karakteristik tertentu yang ditetapkan oleh peneliti untuk dipelajari dan kemudian ditarik kesimpulannya. Populasi yang akan menjadi objek dalam penelitian ini adalah Indek Harga Saham Gabungan pada periode 1 Januari 2018 sampai 15 Juli 2018 terdapat 121 data.

Sampel merupakan bagian atau sejumlah cuplikan tertentu yang di ambil dari suatu populasi dan di teliti secara rinci. Sampel dapat pula diartikan sebagai bagian dari jumlah dan karakteristik yang dimiliki oleh suatu populasi. Sampel dalam penelitian ini adalah yang memenuhi criteria pengambilan sampel

Metode yang digunakan adalah purposive sampling, yaitu penentuan sampel atas dasar strategi kecakapan atau pertimbangan pribadi semata yang disesuaikan dengan tujuan dan masalah penelitian.Dalam penelitian ini, sampel diambil berdasarkan kriteria yang penulis tetapkan, yaitu:

a. IHSG yang diumumkan BEI selama periode penelitian yaitu Januari 2018-15 Juli 2018.

b. Data yang lengkap selama periode penelitian.

\section{Metode Analisis Data}

Pengujian ini menggunakan analisis deskriptif, pengujian asumsi klasik, analisis regresi dan pengujian hipotesis.

\section{Analisis Deskriptif}

Merupakan penelitian yang bertujuan untuk membuat deskripsi atau gambaran mengenai suatu data agar dapat dipahami oleh pembaca. Analisis ini menjelaskan berbagai karakteristik data rata-rata (mean), jumlah (sum), standar deviation, variance, nilai minimum dan maximum.

\section{Uji Normalitas Data}

Uji normalitas data terlebih dahulu dilakukan untuk mengetahui apakah data berdistribusi normal atau tidak. Normalitas data merupakan syarat pokok yang harus dipenuhi dalam analisis parametrik. Normalitas data merupakan hal yang paling penting karena dengan data yang terdistribusi normal, maka data tersebut dianggap dapat mewakili populasi. Salah satu metode uji normalitas adalah dengan metode Liliefors dengan Kolmogorov-Smirnov dan Shapiro-Wilk. Untuk metode Kolmogorov-Smirnov, kriteria pengujiannya adalah sebagai berikut :

Jika signifikasi $<0,05$ maka data tidak berdistribusi normal.

Jika signifikasi $>0,05$ maka data berdistribusi normal. 


\section{Uji Asumsi Klasik}

Pengujian asumsi klasik dilakukan untuk memastikan bahwa multikolinieritas, heterokedastisitas, dan autokorelasi tidak terdapat dalam penelitian ini atau data yang dihasilkan berdistribusi normal. Apabila hal tersebut tidak ditemukan maka asumsi klasik regresi telah terpenuhi. Pengujian asumsi klasik ini terdiri:

- Uji Normalitas Residual

Uji normalitas pada model regresi digunakan untuk menguji apakah nilai residual yang dihasilkan dari regresi terdistribusi secara normal atau tidak. Model regresi yang baik adalah yang memiliki nilai residual yang terdistribusi secara normal. Beberapa metode uji normalitas, yaitu dengan melihat penyebaran data pada sumber diagonal pada grafik normal P-P Plot of regression standardized residual, kriteria pengujian:

Jika titik - titik menyebar sekitar garis dan mengikuti garis diagonal, maka nilai residual tersebut telah normal.

- Uji Multikolinieritas

Uji Multikolinieritas ini bertujuan untuk menguji apakah model regresi ditemukan adanya hubungan antara variabel bebas. Model regresi yang baik seharusnya tidak terjadi korelasi diantara variabel independen. Multikolinieritas dapat dilihat dari korelasi antara masing - masing variabel independen. Jika antara variabel independen ada korelasi yang cukup tinggi (biasanya di atas 0,90), maka kejadian ini mengindikasikan adanya multikolinieritas. Cara mendeteksi ada tidaknya multikolinieritas tersebut dapat dilakukan dengan melihat nilai tolerance dan variance inflation factor (VIF). Kedua ukuran ini menunjukkan setiap variabel independen manakah yang dijelaskan oleh variabel independen lainnya. Nilai cut off yang dipakai untuk menunjukan adanya multikolinieritas adalah apabila nilai VIF $<10$ dan tolerance $>0,10$, maka dinyatakan tidak terjadi multikolinieritas.

- Uji Heteroskedastisitas

Uji hesteroskedastisitas digunakan untuk menguji apakah dalam sebuah model regresi terjadi ketidaksamaan varians dari residual pada setiap pengamatan. Jika dalam varians dari residual satu pengamatan ke pengamatan lain tetap, maka disebut homokedastisitas dan jika berbeda disebut heteroskedastisitas. Uji heteroskedastisitas dalam penelitian ini dengan melihat pola titik-titik pada grafik regresi. Kriteria pengujian :

1. Jika ada pola tertentu seperti titik-titik yang ada membentuk suatu pola tertentu yang teratur (bergelombang, melebar kemudian menyempit), maka terjadi heteroskedastisitas.

2. Jika tidak ada pola yang jelas, seperti titik-titik menyebar di atas dan di bawah angka 0 pada sumbu Y, maka tidak terjadi heteroskedastisitas.

\section{- Pengujian Autokorelasi}

Autokorelasi sering dikenal dengan nama korelasi serial dan sering ditemukan pada data serial waktu (time series). Uji autokorelasi bertujuan mengujiapakah dalam model regresi ada korelasi antara kesalahan pengganggu pada periode $\mathrm{t}$ dengan kesalahan pengganggu pada periode t-1 (sebelumnya). Model regresi yang baik adalah regresi yang bebas dari autokorelasi. Alat ukur yang digunakan untuk mendeteksi adanya autokorelasi dalam penelitian ini menggunakan tes Durbin-Watson(D-W).

\section{PEMBAHASAN}

Populasi yang digunakan dalam penelitian ini adalah seluruh Indek saham gabungan Pada Pasar Modal Indonesia periode 1 Januari 2018 sampai dengan 15 Juli 2018. Sampling diambil dengan metode purposive sampling. Berdasarkan kriteria yang telah ditentukan maka sampel yang memenuhi kriteria sebanyak 93 sampel dari 121 data Indek Harga Saham Gabungan pasar Modal Indonesia. 


\section{UJI NORMALITAS DATA}

Tests of Normality

\begin{tabular}{|l|r|r|r|r|r|r|}
\hline \multirow{2}{*}{} & \multicolumn{3}{|c|}{ Kolmogorov-Smirnov $\mathrm{a}^{\mathrm{a}}$} & \multicolumn{3}{|c|}{ Shapiro-Wilk } \\
\cline { 2 - 7 } & Statistic & \multicolumn{1}{c|}{$\mathrm{df}$} & \multicolumn{1}{c|}{ Sig. } & \multicolumn{1}{c|}{ Statistic } & df & \multicolumn{1}{c|}{ Sig. } \\
\hline IHSG & .081 & 91 & .188 & .950 & 91 & .062 \\
\hline INF & .256 & 91 & .080 & .816 & 91 & .061 \\
\hline KURS & .150 & 91 & .100 & .951 & 91 & .072 \\
\hline BI RATE & .492 & 91 & .120 & .494 & 91 & .060 \\
\hline HRG EMAS & .055 & 91 & $.200^{*}$ & .986 & 91 & .432 \\
\hline INDEKS DJ & .064 & 91 & $.200^{*}$ & .989 & 91 & .641 \\
\hline * This is a lower bound of the true significance.
\end{tabular}

a. Lilliefors Significance Correction

Pengujian dari setiap variabel diperoleh nilai signifikansi $>0.05$, yang menunjukan bahwa data berdistribusi normal.Hal ini menunjukan data dapat mewakili populasinya.

\section{UJI ASUMSI KLASIK}

\section{- Uji Multikolinieritas}

Uji multikolinieritas ini bertujuan untuk menguji apakah model regresi ditemukan adanya hubungan antara variabel bebas. Model regresi yang baik seharusnya tidak terjadi korelasi diantara variabel independen. Untuk menguji multikolinieritas dapat dilihat dari output SPSS pada nilai tolerance dan nilai VIF (Variance Inflation Faktor). Berdasarkan nilai tolerance, nilai yang terbentuk harus di atas 0,10 dan bila menggunakan VIF, nilai yang terbentuk harus diantara 1 sampai dengan 10 (1-10).

\begin{tabular}{|c|c|c|c|c|c|c|c|c|}
\hline \multicolumn{9}{|c|}{ Coefficients $^{a}$} \\
\hline & \multirow[b]{2}{*}{ Model } & \multicolumn{2}{|c|}{$\begin{array}{c}\text { Unstandardized } \\
\text { Coefficients }\end{array}$} & \multirow{2}{*}{$\begin{array}{c}\text { Standardized } \\
\text { Coefficients } \\
\text { Beta }\end{array}$} & \multirow[b]{2}{*}{$t$} & \multirow[b]{2}{*}{ Sig. } & \multicolumn{2}{|c|}{$\begin{array}{l}\text { Collinearity } \\
\text { Statistics }\end{array}$} \\
\hline & & B & Std. Error & & & & $\begin{array}{c}\text { Toleranc } \\
\mathrm{e}\end{array}$ & VIF \\
\hline \multirow[t]{6}{*}{1} & (Constant) & 18.338 & 4.459 & & 4.112 & .000 & & \\
\hline & INF & .052 & .109 & .037 & .481 & .631 & .536 & 1.864 \\
\hline & KURS & -2.037 & .188 & -.776 & -10.809 & .000 & .602 & 1.662 \\
\hline & BI RATE & -.021 & .044 & -.037 & -.473 & .637 & .503 & 1.988 \\
\hline & HRG EMAS & .399 & .276 & .106 & 1.449 & .151 & .574 & 1.742 \\
\hline & INDEKS DJ & .442 & .163 & .179 & 2.715 & .008 & .709 & 1.410 \\
\hline
\end{tabular}

Tabel diatas dapat diketahui bahwa nilai Variance Inflaction Factor (VIF) dari ketiga variabel, yaitu inflasi, nilai tukar rupiah, dan BI rate adalah kurang dari 10 dan nilai tolerance diatas 0.10 sehingga dapat disimpulkan bahwa antar variabel, inflasi, Kurs, BI Rate,Harga Emas Dunia dan Indeks Dow Jones tidak terjadi persoalan multikolinieritas.

\section{Uji Heteroskedastisitas}

Pengujian ini bertujuan untuk menguji apakah dalam model regresi terjadi ketidaksamaan variance dari residual satu pengamatan ke pengamatan yang lain. Berikut cara untuk mendeteksi ada tidaknya heteroskedastisitas yaitu dengan melihat grafik plot antara nilai prediksi variabel terikat (dependen) yaitu ZPRED dengan residualnya ZRESID. Deteksi ada tidaknya heteroskedastisitas dapat dilakukan dengan melihat ada tidaknya pola tertentu pada grafik scatterplot

\section{Uji Autokorelasi}

Tujuan pengujian ini adalah untuk mengetahui ada tidaknya korelasi antar sampel yang dipilih dalam penelitian yang disusun menurut time series. Uji Autokorelasi bertujuan mengetahui 
apakah terjadi korelasi antara data pengamatan, dimana munculnya suatu data dipengaruhi oleh data sebelumnya. Penyimpangan autokorelasi dalam penelitian diuji dengan uji Durbin Watson (DW).

\begin{tabular}{|l|r|r|r|r|r|}
\hline & & & \multicolumn{1}{c|}{$\begin{array}{c}\text { Adjusted R } \\
\text { Square }\end{array}$} & $\begin{array}{c}\text { Std. Error of the } \\
\text { Estimate }\end{array}$ & Durbin-Watson \\
\hline 1 & $.858^{\mathrm{a}}$ & .737 & .721 & .0247022 & 1.350 \\
\hline
\end{tabular}

a. Predictors: (Constant), INDEKS DJ, BI RATE, HRG EMAS, KURS, INF

b. Dependent Variable: IHSG

Nilai DW 1,350, nilai ini lebih dari satu atau lebih kecil dari tiga, maka dapat disimpulkan bahwa model regresi dalam penelitian tidak terjadi autokorelasi.

Selanjutnya dilakukan Uji F guna melihat pengaruh variabel independen secara simultan terhadap variabel dependen. Untuk melihat hasil pengujian dapat dilihat pada tabel Anova.

\section{Uji Hipotesis}

\section{Coefficients $^{\mathrm{a}}$}

\begin{tabular}{|c|c|c|c|c|c|c|}
\hline \multirow{2}{*}{\multicolumn{2}{|c|}{ Model }} & \multicolumn{2}{|c|}{\begin{tabular}{|l|l|} 
Unstandardized \\
Coefficients
\end{tabular}} & \multirow{2}{*}{\begin{tabular}{|l}
$\begin{array}{l}\text { Standardized } \\
\text { Coefficients }\end{array}$ \\
Beta \\
\end{tabular}} & \multirow[b]{2}{*}{$\mathrm{t}$} & \multirow[b]{2}{*}{ Sig. } \\
\hline & & B & Std. Error & & & \\
\hline \multirow[t]{6}{*}{1} & (Constant) & 18.338 & 4.459 & & 4.112 & .000 \\
\hline & INF & .052 & .109 & .037 & .481 & .631 \\
\hline & KURS & -2.037 & .188 & -.776 & -10.809 & .000 \\
\hline & BI RATE & -.021 & .044 & -.037 & -.473 & .637 \\
\hline & $\begin{array}{l}\text { HRG } \\
\text { EMAS }\end{array}$ & .399 & .276 & .106 & 1.449 & .151 \\
\hline & \begin{tabular}{|l|} 
INDEKS \\
DJ \\
\end{tabular} & .442 & .163 & .179 & 2.715 & .008 \\
\hline
\end{tabular}

a. Dependent Variable: IHSG

\begin{tabular}{|l|l|r|r|r|r|r|}
\hline \multicolumn{2}{|l|}{ Model } & Sum of Squares & df & Mean Square & F & Sig. \\
\hline \multirow{3}{*}{1} & Regression & .145 & 5 & .029 & 7.521 & $.000^{\mathrm{b}}$ \\
\cline { 2 - 8 } & Residual & .052 & 85 & .001 & & \\
\cline { 2 - 8 } & Total & .197 & 90 & & & \\
\hline
\end{tabular}

a. Dependent Variable: IHSG

b.Predictors: (Constant), INDEKS DJ, BI RATE, HRG EMAS, KURS, INF

Pengujian dengan uji $\mathrm{F}$ menunjukkan nilai signifikan yang diperoleh lebih kecil dari 0,05 maka $\mathrm{H}_{0}$ ditolak dan $\mathrm{H}_{1}$ diterima sehingga disimpulkan bahwa Inflasi, Kurs,BI rate,Harga emas dan Indeks Dow Jone secara simultan berpengaruh terhadap Indek Harga Saham Gabungan.

Dari hasil Uji t, secara parsial yang mempengaruhi Indeks Harga Saham Gabungan adalah Kurs dan Indeks Dow Jones. Hal tersebut dapat dilihat dari tabel berikut ini:

Hal ini ditunjukan oleh nilai signifikansi Kurs sebesar 0.000 lebih kecil dari 0.05 maka H1 diterima, Kurs berpengaruh signifikan terhadap Indeks Harga Saham Gabungan. Indeks Dow 
Jone nilai signifikansi lebih kecil dari 0.05 maka H1 diterima, Indeks Dow Jones berpengaruh signifikan terhadap Indeks Harga Saham Gabungan. Sedangkan Inflasi, BI Rate dan harga emas tidak berpengaruh sidnifikan terhadap Indek Harga Saham Gabungan, yang ditunjukan dari tabel diatas nilai signifikansinya lebih besar dari 0.05 artinya $\mathrm{H} 0$ diterima $\mathrm{H} 1$ ditolak maka Inflasi ,BI Rate,dan harga emas tidak berpengaruh secara parsial terhadap Indek Saham Gabungan.

Variabel bebas secara simultan berpengaruh terhadap variabel terikat dan berapa kontribusi pengaruh yang diberikan terlihat dari nilai Adjusted $R$ Square pada tabel Model Summary berikut ini :

\begin{tabular}{|l|r|r|r|c|}
\hline Model & R & R Square & Adjusted R Square & $\begin{array}{c}\text { Std. Error of the } \\
\text { Estimate }\end{array}$ \\
\hline 1 & $.858^{\mathrm{a}}$ & .737 & .721 & .0247022 \\
\hline
\end{tabular}

Sumber : Output SPSS

Kontribusi pengaruh variabel Inflasi,Kurs,BI rate,Harga Emas dan Indeks Done Jones sebesar 0.721 atau sebesar $72 \%$ dan sisanya sebesar $28 \%$ dipengaruhi variabel lain yang tidak diteliti.

\section{PERSAMAAN REGRESI BERGANDA:}

Dari tabel koefisien diatas dapat ditentukan persaman regresi berganda sebagai berikut: $\mathrm{Y}=18.338+0.052$ Inflasi -2.037 Kurs -0.021 BI Rate +0.399 Harga emas +0.442 Indeks DJ

Dari persamaan diatas dapat dijelaskan bahwa jika tidak diperhitungkan Inflasi,Kurs,BI Rate,Harga Emas dan Indeks Dow Jones maka Indeks Harga Saham Gabungan (IHSG) senilai 18.338. Jika Kurs,BI Rate,Harga ,harga emas dan indeks Dow Jones konstan dan Inflasi mengalami kenaikan sebesar satu satuan maka IHSG akan meningkat sebesar 0.052 satuan. Apabila Kurs meningkat sebesar satu satuan dan variabel lain konstan maka IHSG mengalami penurunan sebesar 2.052. Apabila BI Rate mengalami kenaikan dan variabel lain konstan maka IHSG akan turun sebesar 0.021 satuan. Jika harga emas naik maka IHSG akan naik sebesar 0.399 dan apabila Indeks Dow Jones meningkat maka IHSG akan meningkat sebesar 0.442 satuan.

\section{PENUTUP}

Volatilitas harga saham di pasar modal dapat dilihat melalui Indeks harga saham yang menjadi salah satu barometer bagi investor sebelum melakukan investasi di pasar saham, karena dari Indeks harga saham dapat diketahui situasi gambaran secara umum. Indeks harga saham merupakan ringkasan dari dampak simultan dan kompleks atas berbagai macam faktor yang berpengaruh. Faktor ekonomi sangat besar pengaruhnya terhadap volatilitas pasar saham. Berdasarkan dari uji statistic data diperoleh hasil bahwa Kurs dan Indeks Dow Jones mempengaruhi secara signifikan terhadap volatilitas pasar saham Indonesia,sedangkan Inflasi, BI Rate, dan Harga emas tidak berpengaruh secara signifikan.

Kurs rupiah terhadap Dollar Amerika terdepresiasi sejak awal tahun yaitu Januari 2018, dan terus berfluktuasi. Kondisi ini disebabkan Amerika Serikat mengumumkan suku bunga Fed Fund sampai 2\% dan menambah be masuk produk impor Cina ke Amerika Serikat yang berakibat terjadinya perang dagang karena Cina membalasnya dengan menaikan bea masuk terhadap produk Amerika yang di Impor ke Cina.Hal ini berdampak terhadap pasar modal Indonesia terutama pasar saham.Indeks Dow Jones berpengaruh signifikan terhadap Pasar saham Indonesia hal ini dikarenakan Indeks Dow Jones merupakan gambaran dari kinerja pasar modal Amerika Serikat. Kebijakan Bea masuk dan kenaikan suku bunga yang disebabkan krisis yang 
dialami Amerika mengakibatkan berdampak tidak baik terhadap Indeks Dow Jone yang mempengaruhi negara berkemban seperti Indonesia. Oleh karena itu pemerintah harus segera menstabilkan nilai tukar rupiah yang terdepresiasi untuk mencegah terjadinya krisis ekonomi yang berdampak pada Pasar saham Indonesia.

\section{DAFTAR PUSTAKA}

Abdul Halim. 2015. Auditing (Dasar-Dasar Audit Laporan Keuangan). Jilid 1. Edisi Kelima. UPP STIM YKPN: Yogyakarta.

Ainur Rachman. 2015. Pengaruh Inflasi, Nilai Tukar Rupiah, BI Rate terhadap Net Asset Value Reksadana Saham Syariah.

Akbar maulana. 2013. Pengaruh SBI, Jumlah Uang Beredar, Inflasi terhadap Kinerja Reksadana Saham di Indonesia periode 2004-2012.

Augustina Kurniasih dan Leonardo David Yuliandy Johannes. 2015. Analisis Variabel Makro Ekonomi terhadap Kinerja Reksadana Campuran.

Ayu Athifah Naufalianty. 2014. Analisis Pengaruh Inflasi dan (BI Rate) terhadap Kinerja Reksadana Saham di Indonesia tahun 2011-2013.

Brigham Huston. 2014. Dasar - dasar Manajemen Keuangan. Buku Dua. Edisi Kesebelas. Jakarta : Penerbit Salemba Empat

Denny Hermawan dan Ni Luh Putu Wiagustini. 2016. Pengaruh Inflasi, Suku Bunga, Ukuran Reksadana, dan Umur Reksadana terhadap Kinerja Reksadana.

Diko Surya Nugraha. 2015. Faktor-faktor yang Mempengaruhi Keputusan Investor Berinvestasi pada Reksadana Syariah.

Duwi Priyatno. 2010. SPSS 22 (Pengolah Data Terpraktis). Penerbit Andi cetakan kedua.

Febrian Dwi Setyarini. 2015. Pengaruh SBIS, Inflasi, Nilai Tukar Rupiah, Jumlah Uang Beredar, dan IHSG terhadap Nilai Aktiva Bersih Reksadana Syariah periode 2009-2013.

Hedi sasrawan. "Reksadana Artikel Lengkap", diakses pada 13 April 2018, dari http://hedisasrawan.blogspot.co.id

Herlina Utami Dwi Ratna Ayu Nandari. 2017. Pengaruh Inflasi, Kurs, dan BI Rate terhadap Nilai Aktiva Bersih Reksadana Syariah di Indonesia periode 2010-2016.

Nurul Huda dan Mustafa Edwin Nasution. 2014. Investasi Pada Pasar Modal Syariah. Kencana, Jakarta.

Irsan Tricahyadinata. 2016. Indeks Harga Saham Gabungan (IHSG) dan Jakarta Interbank Offered Rate (JIBOR) terhadap Kinerja Reksadana Campuran.

Irham Fahmi. 2016. Pengantar Manajemen Keuangan.

Itsna Shofi Azkiyah. 2017. Pengaruh Bank Indonesia (BI) Rate, Inflasi, dan Nilai Tukar Rupiah (Kurs) terhadap Nilai Aktiva Bersih (NAB) Reksadana Campuran Syariah periode 20142016.

J.P Sitanggang. 2014. Manajemen Keuangan Perusahaan. Edisi Kedua. Mitra Wacana Media.

Kasmir. 2014. "Dasar-dasar Perbankan". PT RajaGrafindo Persada, Jakarta.

Karya dan Syamsuddin. 2016. Makro Ekonomi: Pengantar Untuk Manajemen. PT Raja Grafindo Persada, Jakarta.

Kasyfurrohman Ali. 2012. Analisis Pengaruh Variabel Ekonomi terhadap Reksadana Syariah di Indonesia.

Manan. 2012. Hukum Ekonomi Syariah: Dalam Perspektif Kewenangan Peradilan Agama. Kencana, Jakarta.

Nunuk Nurlaili. 2012. Pengaruh Indeks Harga Saham Gabungan dan Rate Bank Indonesia terhadap Nilai Aktiva Bersih Reksadana Saham.

Nurifah. 2017. Faktor-Faktor yang Mempengaruhi Gejolak Perubahan Nilai Aktiva Bersih (NAB) Reksadana Syariah di Indonesia periode 2011-2015. 
Nurna Malya. 2017. Pengaruh Inflasi, dan BI Rate terhadap Portofolio Reksadana Syariah di Indonesia periode 2011-2015.

Rizki Noval. 2017. Pengaruh Indeks Harga Konsumen dan Jumlah Uang Beredar terhadap Nilai Aktiva Bersih Reksadana Syariah.

Pipit Citraningtiyas. 2016. Analisis Pengaruh Inflasi, Bank Indonesia Rate, Nilai Tukar Rupiah terhadap Nilai Aktiva Bersih Danareksa Syariah Berimbang periode Januari 2012Desember-2014.

Prathama Rahardja dan Mandala Manurung. 2014."Teori Ekonomi Makro".Edisi 5, Fakultas Ekonomi Universitas Indonesia, Jakarta.

Rudiyanto. 2016. "Reksadana Untuk Pemula". PT Elex Media Komputindo Kompas Gramedia Building, Jakarta.

Sadono Sukirno. 2015."Makroekonomi Teori Pengantar".PT Raja Grafindo Persada, Jakarta.

Samsul, Mohamad. (2015). Pasar Modal \& Manajemen Portofolio, Edisi 2. Jakarta : Erlangga.

Sukamulja,Sukmawati,2017."Pengantar Pemodelan Keuangan dan Analisis Pasar Modal", Yogyakarta:Penerbit ANDI.

Tjipto Darmadji, Hendy M. Fakhruddin. 2011. Pasar Modal Di Indonesia. Edisi Ketiga. Jakarta : Penerbit Salemba Empat.

www.ariabapepam.go.id

www.bareksa.com

www.bi.go.id

www.bps.go.id

www.ojk.go.id

www.pusatdata.kontan.co.id 